\title{
COMUNICACÃO
}

\section{Phytophthora nicotianae na rizosfera de tomateiro e berinjela no Sudeste da Bahia.}

\author{
Marcos Vinícius Oliveira dos Santos ${ }^{1}$; Edna Dora Martins Newman Luz ${ }^{1,2}$.
}

${ }^{1}$ Programa de Pós-Graduação em Produção Vegetal, DCAA, Universidade Estadual de Santa Cruz, CEP 45662-000 - Ilhéus, BA; ${ }^{2}$ Centro de Pesquisas do Cacau, CEPLAC, CEP 45600-970 - Ilhéus, BA. E-mail:

Autor para correnpondência: Marcos Vinícius Oliveira dos Santos (mvos@oi.com.br)

Data de chegada: 09/11/2009. Aceito para publicação em: 08/06/2010.

O jiló (Solanum gilo Raddi), o tomateiro (Solanum lycopersicum L.) e a berinjela (Solanum melongena L.) são cultivadas em propriedades rurais direcionadas à agricultura familiar no Sudeste da Bahia. Embora estas espécies sejam hospedeiras de Phytophthora spp., não há registro de infecções causadas por estes fitopatógenos nestes cultivos no Estado. Da rizosfera de plantas doentes de berinjela e tomateiro, foram obtidos através de diluição do solo em placas com meio seletivo PARPH (Kanmwischer, M.E.; Mitchell, D.J. Phytopathology 68: 1760-1765. 1978), entre agosto e setembro de 2008 , isolados de Phytophthora sp. que na coleção de Phytophthora Arnaldo Medeiros da CEPLAC receberam os números 1187, obtido de tomateiro no município de Itacaré e 1176, 1177 e 1178 de berinjela em horta no município de Itabuna. As colônias destes isolados, foram repicadas para placas com meio seletivo e a seguir para cenoura-ágar (CA), água esterilizada e caldo de cenoura e incubadas a $25^{\circ} \mathrm{C}$, sob iluminação contínua, para caracterização morfológica. Após sete dias, nas culturas em CA, observou-se a forma das colônias e o tipo de micélio aéreo. Os isolados formaram predominantemente colônias estreladas no centro e difusas nas margens, possuindo micélio aéreo ligeiramente cotonoso (isolados de berinjela) ou ralo (isolado de tomateiro). Lâminas foram preparadas a partir de colônias nos diferentes substratos e medidos 50 esporângios e clamidósporos de cada um dos isolados. Os esporângios tinham em média 46,3 $\pm 0,5 \mathrm{x}$ $35,4 \pm 0,4 \mu \mathrm{m}$, relação comprimento/largura 1.3:1, eram papilados, não caducos, predominantemente limoniformes (Figura 1A), formados em esporangióforos com ramificação simpodial irregular. Os poros apicais das papilas tinham $8,6 \pm 0,1 \mu \mathrm{m}$ de abertura e $6,1 \pm 0,1 \mu \mathrm{m}$ de profundidade. Clamidósporos com diâmetro médio de $29,9 \pm 0,5 \mu \mathrm{m}$ também estavam presentes. Houve a formação abundante de esporângios dos quatro isolados em água (Os isolados esporularam apenas em meio líquido), bem como intumescimentos de hifa em caldo de cenoura. Os isolados são heterotálicos, do tipo compatível A2, de acordo com os testes de compatibilidade sexual realizados (Luz et al. Glossário ilustrado de Phytophthora: técnicas especiais para o estudo de Oomicetos 204p. 2008), com anterídios anfígenos. Lesões típicas (Figuras 1B e C) foram formadas em frutos dos hospedeiros de origem (berinjela ou tomateiro) quatro dias após discos de colônias em CA, com cinco dias de idade, serem colocados diretamente sobre dois pontos da superfície de cada um dos cinco frutos/hospedeiro/isolado inoculados. O reisolamento foi positivo para todos os isolados, cujas colônias cresceram a $35^{\circ} \mathrm{C}$. Todas as características estão de acordo com as já relatadas para Phytophthora nicotianae Breda de Haan (Erwin, D.C.; Ribeiro, O.K. Phytophthora diseases worldwide 561p. 1996; Stamps et al. Revised tabular key to the genus Phytophthora 28p. 1990; Waterhouse, G.M. Key to the species of Phytophthora de Bary 22p. 1963). Este é o primeiro registro desta espécie na rizosfera de plantas de tomateiro e de berinjela no estado da Bahia. Há registro desta espécie como patógeno de frutos de tomate e de berinjela no estado de São Paulo (Siqueira et al. Índice de doenças de hortaliças no Brasil: Bactérias e fungos 89p. 1985; Vitti et al. Fitopatolologia Brasileira 18: 566. 1993).
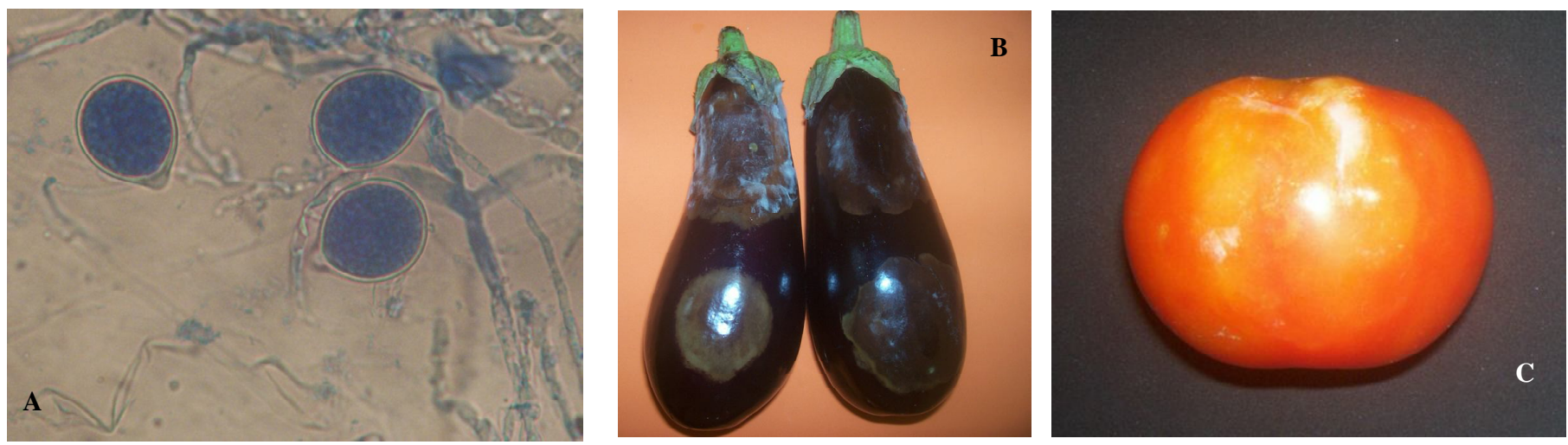

Figura 1. Esporângios do isolado de P. nicotianae obtido da rizosfera de tomateiro (A); frutos de berinjela (B), e tomateiro (C) inoculados com isolados de $P$. nicotianae obtidos na rizosfera dos respectivos hospedeiros. 